細菌のトリプトファン代謝に関する研究

\author{
第 2 編 \\ 腸チフス菌のトリプトフフン代謝 \\ 岡山大学医学部微生物学教室（指導 : 村上 栄教授) \\ 稲田実
}

〔昭和 34 年 4 月 6 日受稿〕

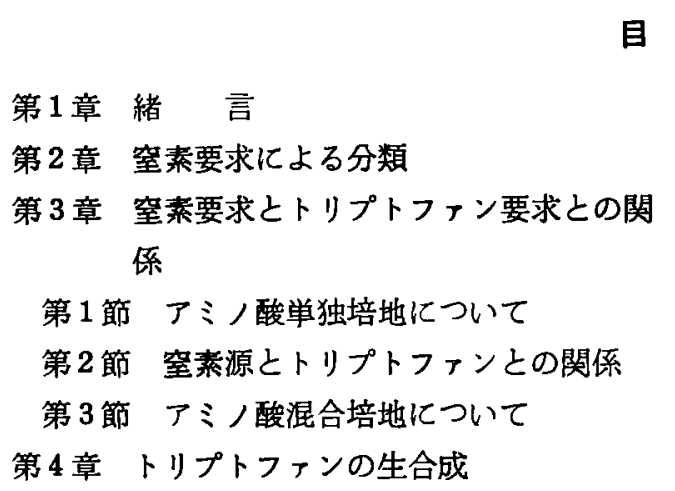

第1章 緒言

腸チフス菌か，その発育に必須のアミノ酸として トリプトファンを要求するととは Koser, Rettger1) (1919), Fildes, Gladstone and knight2) (1933),

Johnson, Rettger $\left.{ }^{3}\right)$ (1942, 1943), 取 4) (1952)

等の埌告せる処であるが, 一方 Van Loghem5) (1911), Braun and Cahn-Bronner6) (1921, 1922), Burrows7)（1939）等は腸チフス菌の或る株は単に $\mathrm{NH}_{3}$ 塩だけを $\mathrm{N}$ 源として発育し得るととを指摘し ている.

又 Fildes (1933)2) 等及び Burrow87) はトリプ トファン必要株の中には training によつてトリプ トファンを必要とせざるに至る菌株の存在するとと を報告している.

著者は当教室保存の腸チフス菌10株を用いて，腸 チフス菌に於けるトリプトフェンの意義を検討した。

\section{第 2 章窒買要求による分類}

腸チフス菌は発育にトリプトフォンを必要とする と言われているか， その点を中心にして率率要求の 立場から，当教室保存の腸チフス菌10株を分類して みた。
次

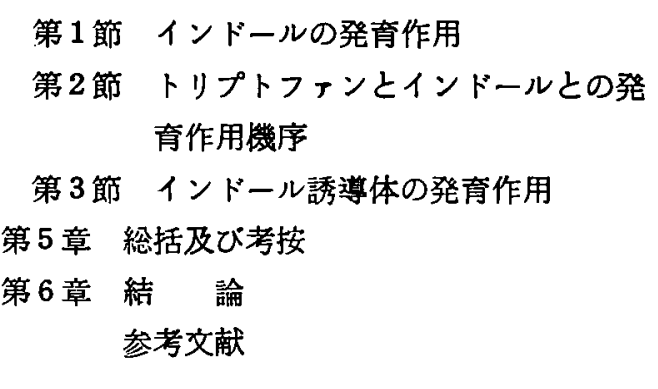

\section{実赜材料及び実験方法}

1）供試菌，当教室保存の腸チフス菌10株を用い た.

2）使用培地, Saunder, 8) 取，4）新井9）の培 地を参照して次の 3 種類の培地を作つた.

A 培地

$\begin{array}{lr}\mathrm{Na}_{2} \mathrm{HPO}_{4} \cdot 12 \mathrm{H}_{2} \mathrm{O} & 1.4 \mathrm{~g} \\ \mathrm{KH}_{2} \mathrm{PO}_{4} & 1.0 \\ \mathrm{NaCl} & 2.0 \\ \mathrm{MgSO}_{4} \cdot 7 \mathrm{H}_{2} \mathrm{O} & 0.1 \\ \mathrm{NH}_{4} \mathrm{Cl} & 0.5 \\ \left(\mathrm{NH}_{4}\right)_{2} \mathrm{SO}_{4} & 0.5 \\ \text { グルコース } & 2.0 \\ \text { 水 } & 1000.0\end{array}$

B 培地

$\begin{array}{lr}\mathrm{Na}_{2} \mathrm{HPO}_{4} \cdot 12 \mathrm{H}_{2} \mathrm{O} & 1.4 \mathrm{~g} \\ \mathrm{KH}_{2} \mathrm{PO}_{4} & 1.0 \\ \mathrm{NaCl} & 2.0 \\ \mathrm{MgSO}_{4} \cdot 7 \mathrm{H}_{2} \mathrm{O} & 0.1 \\ \text { グルタミン酸 } & 0.5 \\ \text { シスチン } & 0.1 \\ \text { グルコース } & 2.0 \\ \text { 水 } & 1000.0\end{array}$


C 培地

B 培地+トリプトフォン $0.02 \mathrm{~g}$

つた培地にはすべての菌株が初代から殴盛な発育を 示した.

何れの培地む $\mathrm{pH} 7.2$ 亿修正し, $100^{\circ} \mathrm{C}, 15$ 分, 3 回間歇隇菌して使用した。

3）接種菌量, 各菌株の普通寒天斜面に $37^{\circ} \mathrm{C}$, 18 24時間培養せるものの 1 白金耳を，㙎菌生理的 食塩水 $10 \mathrm{ml}$ に浮游させ，その 1 白金耳を夫々上 記 A，B，C の各培地 $4 \mathrm{ml}$ に接種した。

4）培㣪及び継代， $37^{\circ} \mathrm{C}$ に培盖し，24時間毎に 夫ァ同一組成の培地 $4 \mathrm{mI}$ に継代した，継代には 1 白金耳を以てし，5代継代を行つた。

5）発育度の観察，24時間毎に発育による浣濁を 肉眼により観察してH，+，士，一で表した，尚 2 本づつ平行して実験を行いこの平均値を取つた。

実 医 成 續

表 1 に示す如くで, $\mathrm{NH}_{3}$ 塩培地には何れの菌株 も全く発育しなかつた。

表 1 晹チフス菌栋の窒素要求による分類

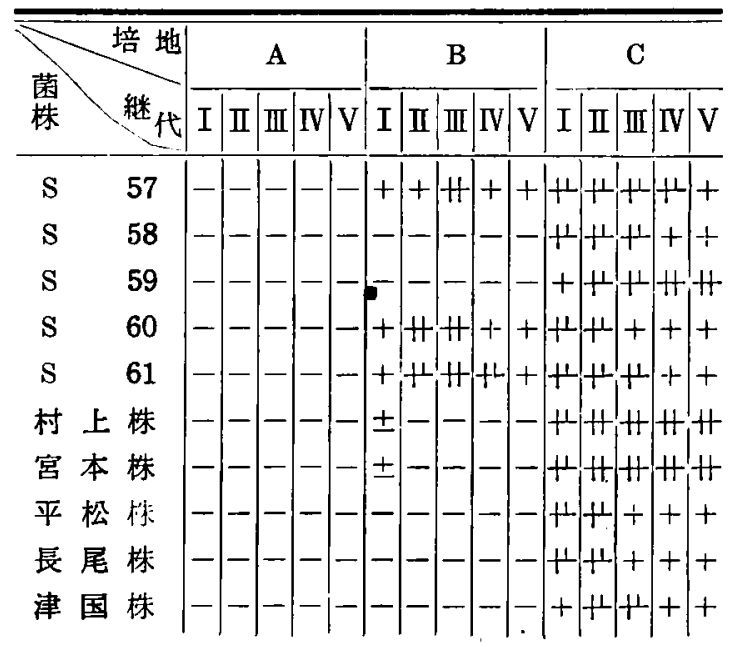

基碟培地の組成

$$
\begin{cases}\mathrm{Na}_{2} \mathrm{HPO}_{4} \cdot 12 \mathrm{H}_{2} \mathrm{O} & 0.14 \% \\ \mathrm{KH}_{2} \mathrm{PO}_{4} & 0.1 \% \\ \mathrm{NaCl} & 0.2 \% \\ \mathrm{MgSO}_{4} \cdot 7 \mathrm{M}_{2} \mathrm{O} & 0.01 \% \\ \text { グルース } & 0.2 \%\end{cases}
$$

A 培地は基碟培地 $+\mathrm{NH}_{3}$ 䇥

B培地は基焚培地十クルタミン酸 (M/60) 十ンスキン $(M / 500)$

$\mathrm{C}$ 培地は基濋培地十グルタミン酸 (M/60)

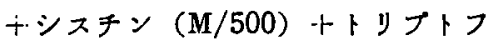
เン (10-4 M)

発青度は肉眼により+，一で表はす

グルタミン酸，シスチン培地には S 57, S 60, S61の 3 株のみが良好な発育を示し，5代継代可 能であつたか，他の 7 梾は全く発青しなかつた。 グルタミン酸, シスチンにトリプトフェンが加わ

これをもつてみるに，呿素源として無機の窒素で は発育のみられる菌株は全く存在せず, s 57, s 60, S 61 の 3 株はアミ/窒素としてグルタミン酸及び シスチンがあれば発育できる菌株であり，他の 7 株 はグルタミン酸及びシスチン丈では発育はみられず， 之にトリプトファンが加わると始めて旺盛な発育を 示した。

即ち, S 57, S60，S61 の3 株はトリプトフォン がなくても発育し得るが，他の 7 株，S58，S59，村 上，宮本，平松，長尾，津国株はトリプトフェンが なくては発育し得ないと思われる。

当教室の腸チフス菌10株の内， 3 株はトリプトフ ァン不要株であり，あとの 7 株はトリプトフェン必 要株と思われる。

以後，主としてトリプトファン不要株として S60 を，トリプトフィン必要株として S58 を選んで実験 をおしすすめ，必要に応じて他の菌株をあ用いた。

\section{第3章 䇪素要求とトリプトフォ ン要求との関保}

腸チフス泊の殆んどの株がトリプトフォンを必要 としていることが分つたが，そのトリプトフォンと 窒素要求との関係をみてみた。

第 1 節 アミ/酸単独培地について

多数のアミノ酸単独培地に菌が発育するかどうか みてみた。

\section{実験材料及ひ実験方法}

1）供試渴， $\mathrm{S} 58$ 及び $\mathrm{S} 60$

2）使用培地, Saunder の培地を参考にして次の 基潹培地を作つた。

$\begin{array}{lr}\mathrm{Na}_{2} \mathrm{HPO}_{4} \cdot 12 \mathrm{H}_{2} \mathrm{O} & 1.4 \\ \mathrm{~K} \mathrm{H}_{2} \mathrm{PO}_{4} & 1.0 \\ \mathrm{NaCl} & 2.0 \\ \text { グルコース } & 2.0 \\ \mathrm{MgSO}_{4} \cdot 7 \mathrm{H}_{2} \mathrm{O} & 0.1 \\ \text { 水 } & 1000.0\end{array}$

上記の基礎培地に次に記すアミ/酸を単独に夫々 $0.05 \%$ 加えたアミ/酸単独培地を作つた．但し $\mathrm{dl}$ 体は倍量用いた，尚シスチンは先づ $\mathrm{N} / 10 \mathrm{HCl}$ に, チロジは $\mathrm{N} / 10 \mathrm{NaOH}$ に央々溶かしてから用いた。 $\mathrm{dl}$-アラニン, $l$-グリシン, $l$-ヴァリン, $l$-ロイシ ン, l-シスチン, dl-メチオニン, $l$-アスパラギン酸, $l$-グルタミン酸, $\mathrm{dl}$-リシン, $l$-アルギニン, $l$-ヒス 
チジン, dl-フェニルアラニン, $l$-チロシン, $l$-トリ プトフォン．これらアミノ酸単独培地は夫々 $4 \mathrm{ml}$ づつ試験管に分注, $\mathrm{pH} 7.2$ 亿修正, $100^{\circ} \mathrm{C}, 15$ 分, 3 回間歇滅菌して使用した。

3）接種菌量, 培養及び継代方法, 発育度の镇察 は第2 章と同じ。

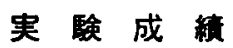

表 2 亿示す如くで, $s 58$ は発育はすべての培地に みられなかつたが， 560 はグルタミン酸，アスパラ ギン酸, シスチン培地に良く発育し 5 代継代可能で あつた。特にグルタミン酸培地には良好な発育を示 した.

\section{表 2 各種単独アミノ酸の発育に及活す影響}

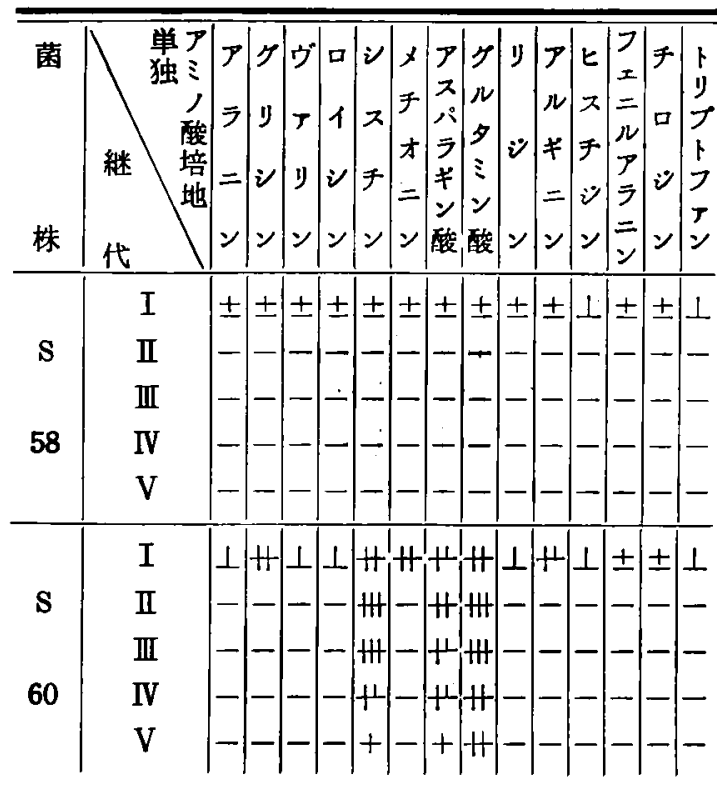

基磷培地は表 1 と同じ

各種単独アミノ酸培地は基礎培地飞各種ア

ミノ酸を0.05\%に加えしもの

発育度は肉眼により+，一で表はす

グリシン,アルギニン，メチオニン培地には初代 には発育がらられたか，2 代以後に継代出来なかつ た.

とてろで両株ともトリプトフォン培地には全く発 育はみられなかつた。トリプトフェン不要株の $\mathrm{S} 60$ はむしろトリプトファン以外のアミノ酸単独培地に 良く発育している。

これをみるにトリプトフェンは単独では意味が無 いととが分る. トリプトフェン必要というととは他 にN源があつてのてとであろう.

そこで，次にN源とトリプトフェンとの関係をみ てみた.
第 2 節 窒素源とトリプトフォンとの関係 $\mathrm{N}$ 源として無僟の $\mathrm{NH}_{3}$ 塩を選び，之にトリプト フェンが加わつた培地にトリプトフォン必要株が発 育し得るかどうか調へた。

\section{実験材料及ひ実酫方法}

1）供試菌, トリプトファン必要株 7 株

2）使用培地，次の $\mathrm{NH}_{3}$ 塩にトリプトフェンの 加わつた培地を使用した。

$\begin{array}{ll}\mathrm{Na}_{2} \mathrm{HO}_{4} \cdot 12 \mathrm{H}_{2} \mathrm{O} & 1.4 \\ \mathrm{KH}_{2} \mathrm{PO}_{4} & 1.0 \\ \mathrm{NaCl} & 2.0 \\ \mathrm{MgSO}_{4} \cdot 7 \mathrm{H}_{2} \mathrm{O} & 0.1 \\ \left(\mathrm{NH}_{4}\right)_{2} \mathrm{SO}_{4} & 5.0 \\ \text { トリプトフナン } & 0.02 \\ \text { グルコース } & 2.0 \\ \text { 水 } & 1000.0\end{array}$

3）接種荣量，培童方法，発育度の観察は第 2 章 之同じで，但し継代は行わなかつた。

\section{実 䀦 成 績}

7 株ともこの培地沉は全く永育しなかつた。即ち， トリプトフェン必要侏は $\mathrm{NH}_{3}$ 塩とトリプトフェン では発育出来ないととが分る。

第 2 章の実験成䥊及びこの実鈳からトリブトフ ン必要侏としては， N源としてアミノ酸の存在を必 要とし，その土台の上にトリプトファン存在の意義 があるのであろう。

そこでこんどは多数のアミノ酸混合培地をつくり， アミノ酸の引き拻き実倹を行い，どのアミノ酸が必 要か調へてみた。

\section{第3 節 アミノ酸绲合培地について 実殹材料及ひ実験方法}

1）供試菌，S 58， S 60

2）使用培地 基管培地としては，第 3 章第 1 節 の場合之同じ組成のものを用いた。

基管培虬任多数のアミノ酸を加えたアミノ酸混合 培地を作つた。

用いたアミノ酸は次の通りである.

アラニン, グリシン, ゼリン, ロイシン, チロジ ソ,グルタミン酸, アスパラギン酸, アルギニン, メチオニン, シスチン, ヒスチジン, トリプトフォ ンの計12種類である.

アミノ酸は夫々 10-3Mo1 濃度に加え，全部つア ミノ酸を加えた培地を M1 とする。

培吔 M1 からアミノ酸を夫タ一つ宛引抜いた培 地を作つた。 
何れの培地む pH 7.2 亿修正して使用した。

3）接種菌量，培養及び継代方法は第 2 章と同じ であるが, 発育度の観察には肉眼によらず光電比色 計によつて発育による湿濁度をしらへ，最高の発育 を100とし，てれに対する比率をむつて表した。

\section{実 成}

表 3 に示す如くで, S58 はトリプトフナンを欠く と全く発育がみとめられず，次いでシスチンを欠く と発育が非常に悪くなり，アスパラギン酸を欠くと 発育が大分劣る.

表 3 アミノ酸引きぬき試験の発有に及ほす影搐

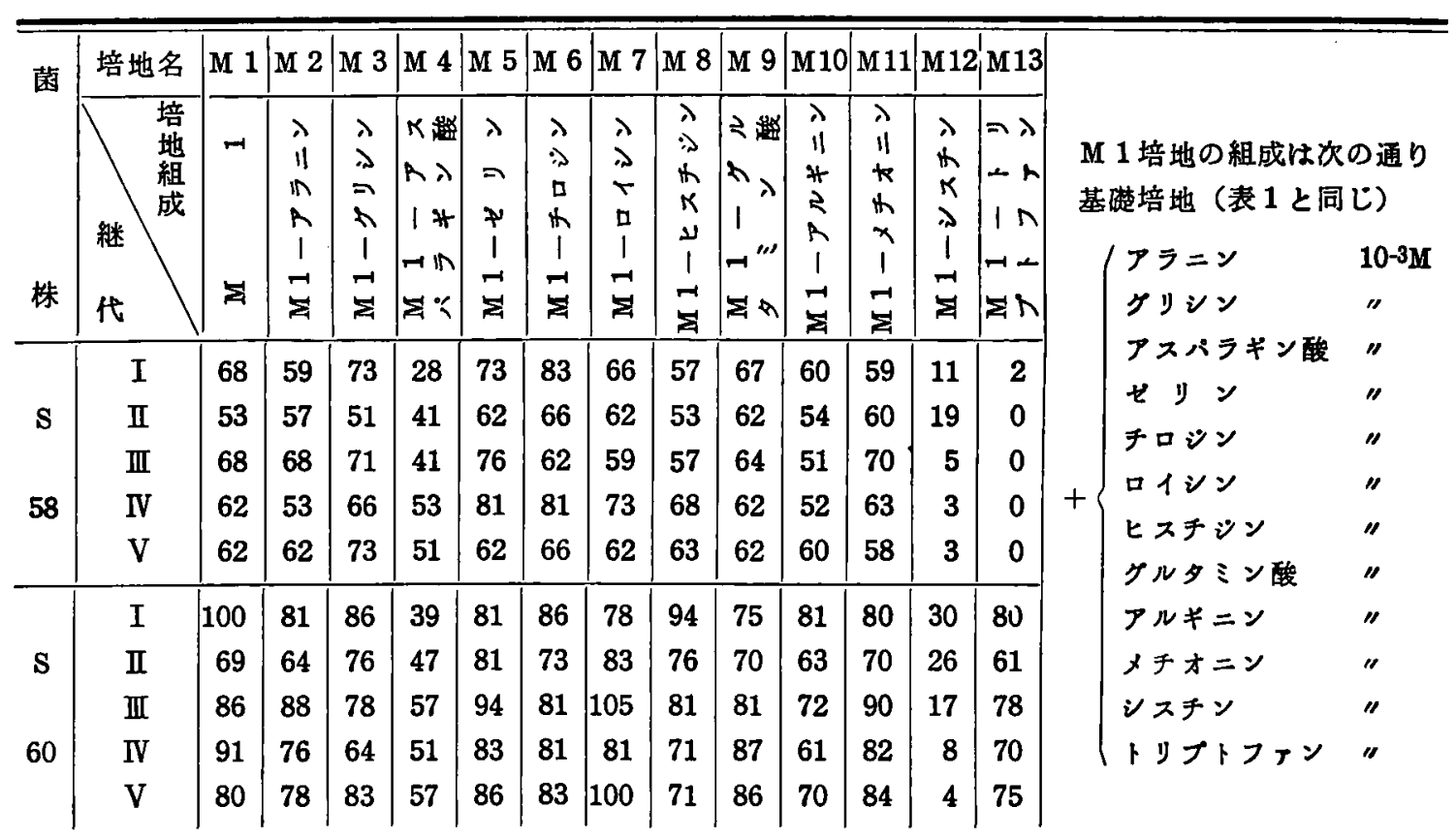

数字は発育度を示す，発育による混摆を光電比色計で求め最高の発育を100とし，他をこれて対す る比率をるつて表した。

之に反して S60 はトリプトフォンを欠いても培 地 M1 と同程度敒発し，むしろシスチンを欠く 之発育が非常に劣り，次いでアスパラギン酸を欠く 之発育が大分劣る。

てれにより $\mathrm{S} 58$ はトリプトフナンを必要として いるとと， $\mathbf{5} 60$ はトリプトフナンを全く必要として いないことが確定された訳である.

シスチンに次いでアスパラギン酸が発育に重大な 影響をすつているてとは両者つ菌侏に共通であつた。 尚， S 源としてシスチンを必要としており，シス チンさえあれは์,メチオニンは無くても差支えない ととが分つた。

他のアミノ酸は発育に殆んど影䈉はない様に思わ れる.

トリプトフォン必要侏である S 58 が, トリプト フォンを含む多数のアミノ酸培地には良く発育する ことが出来るのに, 唯トリプトフォンを欠くと全く 発青がみられないてとは，トリプトフォンの合成が 出来ないるのと思われる。 それに反してトリプトフ
エンがなくても発育する S60 の場合には，トリプ トファンを合成しているものと思われる。

\section{第4章 トリプトフォンの生合成}

では、トリプトフォンは如何にして合成されるで あろうか. 先づトリプトフェンの前取物質として考 えられるものはインドールならびにインドール誘導 体であろう。

そてで, 先づトリプトフォン必要侏のインドール による発育効果をみてみた.

第 1 節 インドールの発育作用

\section{実卧村料及ひ実殹方法}

1）供试菌，トリプトフェン必要株 7 株

2) 使用培地

$\begin{array}{ll}\mathrm{Na}_{2} \mathrm{HPO}_{4} \cdot 12 \mathrm{H}_{2} \mathrm{O} & 1.4 \\ \mathrm{KH}_{2} \mathrm{PO}_{4} & 1.0 \\ \mathrm{NaCl} & 2.0 \\ \mathrm{MgSO}_{4} \cdot 7 \mathrm{H}_{2} \mathrm{O} & 0.1 \\ \text { アスパラギン酸 } & 2.2\end{array}$




$$
\begin{array}{lr}
\text { シスチン } & 0.48 \\
\text { グルコース } & 2.0 \\
\text { 水 } & 1000.0
\end{array}
$$

上記の基礎培地はトリプトフェン又はインドール を夫ょ 10-3M 濃度に加えたトリプトファン培地及 びインドール培地を作つた。

何れす pH 7.2 亿修正して使用した。

3）接種菌量, 培食方法, 発育度の観察は第 2 章 之同じであるが，継代は行わず培養24时間後に判定 した.

\begin{tabular}{|c|c|c|c|c|}
\hline \multicolumn{3}{|c|}{ 菌株 培地 } & $\begin{array}{l}\text { インドール } \\
\text { 培 地 }\end{array}$ & $\begin{array}{c}\text { トプトフラン } \\
\text { 培 }\end{array}$ \\
\hline $\mathbf{S}$ & & 58 & H & $\#$ \\
\hline $\mathbf{S}$ & & 59 & $H$ & H \\
\hline 村 & 上 & 株 & H & $H$ \\
\hline 宮 & 本 & 株 & H & $\#$ \\
\hline 平 & 松 & 株 & H & H \\
\hline 長 & 尾 & 株 & H & $H$ \\
\hline 津 & 国 & 株 & $H$ & $H$ \\
\hline
\end{tabular}

\section{実 硢成 統}

表4亿示した通りであり，全株とあトリプトフォ ン培地,インドール培地に同程度の良い発育を示し

表 4 トリプフェン必要株のインドールK よる発育効果

基繁培地の租成

$\begin{cases}\mathrm{Na}_{2} \mathrm{HPO}_{4} \cdot 12 \mathrm{H}_{2} \mathrm{O} & 0.14 \% \\ \mathrm{KH}_{2} \mathrm{PO}_{4} & 0.1 \% 6 \\ \mathrm{NaCl} & 0.2 \% 6 \\ \mathrm{MgSO}_{4} \cdot 7 \mathrm{H}_{2} \mathrm{O} & 0.01 \% 6 \\ \text { クルコース } & 0.2 \% 6 \\ \text { アスパテキン酸 } & \mathrm{M} / 60 \\ \text { レスチン } & \mathrm{M} / 500\end{cases}$

インドール培地は基脴培地+インドール10-3M

トリフトフォン培地は基礎培地十トリフトフ エン $10-3 \mathrm{M}$

発育度は培養24時間後に肉眼により判定し十, 一で表はす。
た. 即ち、インドールはトリプトフォンに劣らぬ発 充効果を有することが分つた．当教室のトリプトフ フン必要株け全部トリプトフェンがなくてもインド ールがあれげ良く発育することが分つたので，更に 詳しくトリプトフォンとインドールとの発育作用を 比較してみた。

第2節 トリプトフォンとインドールとの

\section{発青作用機序}

\section{実験村料及び実験方法}

1）供試菌 S $58 ，$ S 59

2）使用培地，第 1 節と同じ基礎培地にトリプト フェン及びインドールを夫及 10-3M 10-8 Mol 濃度 に加えた培地を作つた。

3）按種菌量, 培羡方法, 発育度の観察は第 3 章 第 3 節之同じであるが，継代は行わず培養24時間後 に判定した.

\section{実 䀫 成 結}

表 5 亿示した如くで，トリプトフォン及びインド 一ルは共汇両株に於て 10-3M から 10-6 M 法度までは 一様に旺盛な発育効果を示し，10-7M 加らは急に大 分低下した発育效果を表わしたか，同じ浱度に於て は同程度の発育効果を示した。

かくの如く,トリプトフォンとイント゚ールが全く 同程度の発育作用を有することは，トリプトファン がインドールから合成されるむのであるととを推測 させる.

第 3 節 インドール諉導体の発育作用 インドールの発育作用は分つたが，では尚トリプ トファンの前階物質と考えられるインドール誘導体

\begin{tabular}{|c|c|c|c|c|c|c|c|c|}
\hline 菌株 & 検 体 検体添加量 & $10^{-3} \mathrm{M}$ & $10^{-4} \mathrm{M}$ & 10-5 M & $10-6 \mathrm{M}$ & $10^{-7} \mathrm{M}$ & $10-8 \mathrm{M}$ & 0 \\
\hline $\mathbf{s}$ & $1 \vee \vDash-N$ & 93 & 96 & 90 & 84 & 26 & 26 & 0 \\
\hline 58 & トリフトフォン & 100 & 93 & 87 & 83 & 26 & 18 & 0 \\
\hline $\mathbf{s}$ & $1>ト-N$ & 87 & 100 & 96 & 80 & 12 & 3 & 0 \\
\hline 59 & トリブトフォン & 90 & 100 & 90 & 77 & 9 & 3 & 0 \\
\hline
\end{tabular}
の発育効果はどうであろうか。

インドール誘導体としてインドール醌酸及びスカ トールを用いて，インドール及びトリプトフェンの 発育作用と比較してみた。

表 5 トリフトフェンとインドールとの発青作用の比較

基礎培地の組成情 4 と同じ。

数字は発育度を示す。

発青度は培 24 時間後飞判定し，判定方法は表 3 と同じ. 


\section{実酫材料及ひ実酫方法}

1）供試菌, S 58, S 59

2）使用培地，第 1 節之同じ基礎培地を用い，之 にトリプトフェン，インドール，インドール酷酸カ リ，スカトールを夫々 10-2M〜10-6M 濃度に加えた 培地を作つた。

何れも $\mathrm{pH} 7.2$ 亿修正して用いた。

3）接種菌量，培養方法，及び発育度の観察は第 2 章と同じであるが，但し継代估行わす培羡24時間 後及び48時間後に判定した。

\section{実 嗝 成 繹}

表6に示した如くで，両侏ともトリプトファン培 地に於ては 10-2M〜10.6M の澧度に於て，インドー ル培地に於ては 10-3〜10-6M の濃度に於て一様に压 盛な発育を示した。

表 6 インドール倸运伐の発育作用

\begin{tabular}{|c|c|c|c|c|c|c|c|c|}
\hline \multirow{2}{*}{$\begin{array}{l}\text { 菌 } \\
\text { 株 }\end{array}$} & \multirow{2}{*}{ 検 体 } & \multirow{2}{*}{$\left|\begin{array}{l}\text { 培 } \\
\text { 坴 } \\
\text { 時 } \\
\text { 間 }\end{array}\right|$} & \multicolumn{2}{|r|}{ 検 } & 体 添 & 加 & \multicolumn{2}{|l|}{ 量 } \\
\hline & & & $10-2 \mathrm{M}$ & $10^{-3} \mathrm{M}$ & $\left|10^{-4} \mathrm{M}\right|$ & $10-5 \mathrm{M}$ & $10^{-6} \mathrm{M}$ & 0 \\
\hline \multirow{4}{*}{$\mathbf{S}$} & トリブト & 24 & H & $H$ & $H$ & H & H & - \\
\hline & フォン & 48 & H & $H$ & $H$ & H & H & - \\
\hline & インドー & 24 & - & $H$ & $H$ & $H$ & $H$ & - \\
\hline & N & 48 & - & $H$ & H & H & $H$ & - \\
\hline \multirow[t]{4}{*}{58} & $\begin{array}{l}\text { インドー } \\
\text { ル醋酸力 }\end{array}$ & 24 & - & - & + & - & - & - \\
\hline & リ & 48 & - & - & $H$ & - & - & - \\
\hline & スカト一 & 24 & - & + & H & - & - & - \\
\hline & $n$ & 48 & - & $H$ & $H$ & - & - & - \\
\hline \multirow{4}{*}{$\mathbf{S}$} & トリプト & 24 & $H$ & H & H & $H$ & H & - \\
\hline & フォン & 48 & H & H & H & H & H & - \\
\hline & インドー & 24 & - & H & $H$ & $H$ & H & - \\
\hline & $N$ & 48 & - & H & $H$ & H & H & - \\
\hline \multirow[t]{4}{*}{59} & $\begin{array}{l}\text { インドー } \\
\text { ル酩酸力 }\end{array}$ & 24 & - & - & + & - & - & - \\
\hline & y & 48 & - & - & $H$ & - & - & - \\
\hline & スカトー & 24 & - & + & + & - & - & - \\
\hline & $N$ & 48 & - & $H$ & + & - & - & - \\
\hline
\end{tabular}

基碳培地表 4 と同し。.

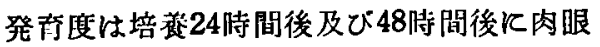
より判定し十，一で表はす。

又、両株ともイント゚ール醁酸カリ培地に於ては 10-4M 濃度に於てのみ, スカトール培地に於ては 10-3M 及び 10-4M 㗳度に於てのみ良好な発育を示 し，他の濃度に於ては全く発育はみられなかつた。

てれによつてみるに，之等インドール誘導体の発
育效果はトリプトフェン及びインドールに，はるか に及ばないことが分つた。

即ちトリプトファンの発育作用はイント゚ールその あのに直結されていると信ぜられる。

\section{第5章 総括 及び考按}

一般に腸チフス菌にとつてトリプトフェンは必要 であると云われているが，てのトリプトフェン必要 というのは如何なる意議かをしらへてみた。

Van Loghem (1911) 5) は大腸菌は勿論であるが, 腸チフス菌11株の内 3 株がフンモニウム塩培地住生 育したので，それまで Fischer10)がN源に対する 要求で大晹菌と腸チフス菌とを区別していたのは正 しくないと述へた。

Koser，Rettger1)（1919）は腸チフス菌はアンモ ニウム塩培地又はアミ/酸単独培地には発育せず， トリプトファンを含むアミノ酸混合培地には発育し たと述へている。

Braun 及び Cahn-Bronner6) (1921，1922）は腸 チフス菌62株の内，18株がアンモニウム塩を唯一の $\mathrm{N}$ 源として発育したか，他の44株は $\mathrm{NH}_{3}$ 塩又は一 群のアミノ酸をN源としても発育せず，トリプトフ エンが加わると始めて発育が得られたと埌告してい ろ.

Fildes，Gladstone 及び Knight2)（1933）は腸 チフス菌 4 株がトリプトファンを含む14のアミノ酸 を含む培地には発育するが、トリプトフナンを欠く と発育がみられないと云つている。

Burrows）（1939）は腸チフス菌を栄養的の見地 から, a) $\mathrm{NH}_{3}$ 塩を唯一の $\mathrm{N}$ 源として発育し得るも の. b)トリプトファンを必要とするもトリプトフ アン無しに発育し得るように trainig し得るもの. c) trainig し得ないものの 3 種に分つととが出来る と述べてい。

Johnson，Rettger3)（1943）はチフス菌 5 株を用 いて，16のアミノ酸を含む培地加らミノ酸引抜き 実験を行い,トリプトフォンを欠いた場合のみ全く 発育がみられないととから，チフス菌にとつてトリ プトファンは必須アミノ酸たるへきととを述へた。

䀈取4（1952）は141株の腸チフス菌を用いて, 腸チフス菌を栄坫要求の立場加ら次の 4 群即ち，A 群, トリプトファン必要侏. B 群, インドール必要 株. $\mathrm{C}$ 群了ミノ酸必要株. $\mathrm{D}$ 群 $\mathrm{NH}_{3}$ 塩必要株. 亿 型別し得るととを指摘した。尚 141 株の内，A群に 属するものは 3 株，B群に属するすのは 119 株，C 
群に属するすのは19株であり，D群に属するものは 無かつたが，C群の中から D群に相当する変異株を つくり出すととが出来たといつている.

筆者は窒秦要求の立場から次のものを夫々含む 3 種。培地，a） $\mathrm{NH}_{3}$ 墥培地，b）グルタミン酸+シ スチン培地. c) グルタ シン酸+シスチントトリプ トフォン培地. を用いて教室保存のチフス菌10株を 分類した。結果は何れの株も $\mathrm{NH}_{3}$ 塩培地には発育 はみられず，10拣の内，3株はN源としてグルタミ ン酸及びシスチンがあれば発育し，他の 7 株はそれ 丈では発育せずグルタミン酸及びシスチンにトリプ トフォンが加わると始めて発育した。

即ち，10株の内，S 57，S 60，S61の 3 株は発育 にトリプトフォンを必要とせず, 他の S 58，S 59， 村上, 宮本, 平松, 長尾, 津国の 7 株はトリプトフ エンを必要としている様に思われることが分つた。

つまり， 7 株はトリプトファン必要株であり，他 の3株はトリプトフォン不要株というととになる.

これでチフス菌の殆んどの株がトリプトフォンを 必要としている様に思われることが分つたので, 次 に更にトリプトファン必要というととと $\mathrm{N}$ 要求との 関係を見てみた。

先づ，14のアミ/酸を用いて，各々のアミ/酸単 独培地に菌が発育するかどうか見てみたが，トリプ トフェン必要株 S58 はどのアミ/酸培地にあ発育は みられなかつた。他方トリプトファン不要株 $\mathrm{S} 60$ は グルタミン酸, アスパラギン酸, シスチン培地俍 く発育した。特にグルタミン酸培地には良好な発育 がみられた。

とてろで，S58，s 60 の両株ともトリプトファン 単独培地には全く発育はみられなかつた。 トリプト フォン不要株の $\mathrm{s} 60$ はむしろトリプトファン以外の アミノ酸単独培地浪く発育している。

このとと及び前述の分類の場合にトリプトファン 必要株はグルタミン酸及びシスチン丈では発育はみ られず,トリプトフェンが加わると始めて発育がみ られた事から，トリプトファンは単独では意味がな く、トリプトフォン必要というととは他にN源が存 在してのととであるてとが分つた。

そてで次にN源とトリプトフェンとの関係をみて みた。

先づN源として $\mathrm{NH}_{3}$ 壏を用い，之にトリプトフ テンが加わつた培地にトリプトフォン必要株が発 育し得るかどうか調ててみたが,トリプトフォン必 要株 7 株とあ全く発育し得なかつた。 即ちトリプト
ファン必要株は $\mathrm{NH}_{3}$ 塩とトリプトファンでは発育 出来ないととが分つた。

このこと及び前述の分類の場合にトリプトファン 必要株はグルタミン酸及びシスチンにトリプトフォ ンが加わると绐めて発育がみられた事から，トリプ トファン必要株としてはN源として他にアミノ酸の 存在を必要とし，その土台の上に更にトリプトフォ ンを必要としているものと思われる.

そこでこんどは多数のアミノ酸混合培地をつくり， 一つ一つアミノ酸の引き抜き実験を行い,どのアミ

ノ酸が必要か調べてみた。

トリプトフォン必要株 S58 はトリプトフォンを欠 いた場合にのみ全く発育はみられなかつた。次いで シスチンを欠くと発育は非常に悪くなり，アスパラ ギン酸を欠くと発育は大分劣つていた。

トリプトフォン不要株 $\mathrm{S} 60$ ではトリプトファンを 欠いても発育は少しも影響されず，むしろシスチン を欠くと発育が非常に劣り，次いでアスパラギン酸 を欠くと発育が大分少つた。

両株とも他のアミノ酸は欠いても発育に殆んど影 㗽はみられなかつた。

両株とす $\mathrm{S}$ 源としてシスチンを必要としており， シスチンさえあればメチオニンはなくてもよいとと が分つた。

又, シスチン及びアスパラギン酸が発育に重大な 影響をむつているととは両株に共通であつた。

このアミノ酸引抜き実験でトリプトフォン必要株 はトリプトフォンを絶対に必要としているととが確 定された訳である。

Fildes 等2)（1933）はチフス菌の栄養要求に於て 14のアミノ酸を用いてアミノ酸引き抜き実験を行い， トリプトフォンを欠いた場合にのみ発育は全く見ら れず，次いでシスチンが発育に重大な影響をもつて おり，他のアミ/酸による僅加の影響は trainngに よつて打勝たれたと報告している。

筆者の場合、アスパラギン酸がやや重大な影響を 持つていたが，との点は Fildes の成續と異なる.

シスチンがチフス菌の発育に重大な影響を及ほす ととは新井9) (1950) む認めており,トリプトフォ ンは，たとえ充分なるN源と共存するともシスチン の一定量が共存せざる場合には発育効果を現わさな いと報告している.

トリプトフォン必要株にとつてトリプトフォンは 絶対に必要な事は分つたが、ではトリプトフォンの 発育に及にす作用機序はどのようであろうか。 
Burrows7)（1939）はトリプトフアンはチフス菌 の発青に促進的勃果を及ぼすとして、トリプトフォ ンの役割について “trigger action”なる表現を用 いている.

新井9）(1950）はチフス菌の或菌株に対してトリ プトフェンが顕著な発育促進作用を有し，而もペプ トンの如き複合せる組成を有する蛋白分解産物中に 於てひとりトリプトフェンのみが卓越せる発育効果 を有する事実を見，尚トリプトフェンが 10-8M 程度 の微量にて充分発育効果を発揮しうる点より考え， 本物質は菌体の発育過程に於けるN源たるの意義よ りむしろ触媒的意義を有する如く思われると述へて いる.

筆者もトリプトフォン必要株 S58, S 59 に於て トリプトファンが 10-8 $\mathrm{M}$ 濃度です発育効果を有する のを見るととが出来た。

先にアミノ酸引き抜き実験に於てトリプトファン 必要株 S58がトリプトフォンを含む多数のアミノ酸 培地に於ては旺盛な発育を示すのに，トリプトフォ ンを欠いた場合にのみ全く発育が見られないとと， 並びに上述のトリプトフォンが 10-8 M という微量で あ発育效果を有することから、トリプトファンはト リプトフォンを必要とするチフス菌にとつて “発有 因子”にあたるむのと解せられる.

先のアミノ酸引き抜き実験に於てトリプトフィン を欠くと全く発育の出来ない 558 の場合はトリプト ファンの合成が出来ないものと思われる，それに反 してトリプトフェンがなくてあ発育できる $\mathbf{5 6 0}$ の場 合にはトリプトファンを合成しているものと思われ る.

では,トリプトファンは如何にして合成されるで あろうか. 先づトリプトフェンの前階物質として考 えられるあのはインドールならびにインドール誘通 体であろう.

Fildes11)（1940）はトリプトフォンを必要とする チフス菌につき，インドール及びスカトール，イン ドールアルデヒド，一醋酸，一カルボキシル酸，ープ ロピオン酸，一アクリル酸，一焦性葡萄酸，一エチラ ミンの 8 種のインドール誘導体による発育効果を見 たが、インドールのみが高い活性を有するととを 認め，チフス菌に於てトリプトフェンはインド 一ル或はこれと同様な他の未知の物啠より合成され るのであろうとして，その合成過程を次の式で示し た.

$\mathrm{NH}_{3}$ 塩又はアミノ酸 $\rightarrow$ イドールートリプトフ
エン

Wooley 及び Sebre1112）（1945）はチフス菌 T-63株に対するインドール， dl-トリプトファン； インドールアルデヒド, 一ヒダントイン, 一チオダ ントイン, 一酷酸, 一プロピオン酸, 一n酩酸の発育 作用を見たが、インドールは dl-トリプトフェンの 3〜4倍の強い発育胶果を有し，インドール醮酸が微 弱乍ら発育效果を有することを報告している。

鷹取4）(1951）はトリプトファン必要株の内, 119 株はインドールでよく発育するが，残りの 3 株はイ ント゚ールでは発育せず，どうしてもトリプトファン を必要としたといつている.

新井9）(1950）はチフス菌が発育時トリプトフォ ンを分解してキヌレニン次いでアントラニール酸を 生成するという大谷，及び本田13）の報告汇鑑み， チフス菌の発育途上に於ける之等トリプトフォン分 解産物が二次的任発育促進作用を有するに非ざるや 之考え，キヌレニン，アントラニール酸の発育効果 を見たが全く陰珄であつたので，トリプトファンの 発育作用としてインドール核の重要性を想像し， 1 ンドール及びインドール倸導体 9 種の発育効果を見 たが、トリプトフェン及びインドールは 10-2\% 10.6\%の濃度に於て略々同程度の显著なる発青効果 を有し，其の他ではインドール醋酸，及びスカトー ルのみが 10-296の濃度に於て微弱な発育效果を示し たと報告している。 そして Fildes11) (1940), Woley 及び Sebrel112（1945）の前記の成績及び自己の成

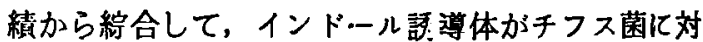
し発育支持能を示す為には，i)，インドール核の 位が空位なること。ii），インドール核の $\beta$ 位か空位 なるか或は $\beta$ 位置換基が特異的構造を有すへきこと。 の諸条件を具備するとと必要なりと述へている.

筆者はトリプトフェン必要株 7 株のインドールに よる発育効果を見たが，何れの株むインドールでト リプトフォンに劣らぬ発㕕を示した. 霍取の如くイ ンドールでは発育せず，どうしてすトリプトファン を必要とする株はなかつた。

インドールがトリプトフェンに劣らぬ発育を示す こと加更に詳しく両者の発育効果を比校してみた 処，トリプトファン，インドール共に 10-3〜10-8M 閧度に於て略々同程度の発育効果を示した。

トリプトファンとインドールの発育効果の比較で は筆者の場合は新井と同じであり，Fildes がインド ールがトリプトフォンと同じ発青を示すには約10倍 の濃度を要すると云い, 又 Wooley がインドール 
はトリプトフォンの約3〜4倍の強い発育効果を有す ると云つたのといささか異なる。

次にインドール諉導体としてインドール醋酸及び スカトールを用いて発育効果をみてみたが、トリプ トファン及びインドールが 10-3〜 10-6M 濃度に於 て昰盛な発育効果を示すのに，インドール醋酸は 10-4M 濃度に於てのみ, スカトールは 10-3M 及び 10-4M 濃度に於てのみ良好な発育効果を示したに過 ぎなかつた。

Wooley 等はチフス菌に対してインドール醋酸が 微弱な発育効果を有するのを見, 新井はインドール 醋酸及びスカトールが 10-296漕度に於て発育効果 を有するのを見たが，筆者す同様にインドール醋酸 及びスカトールがチフス菌に対して発育作用を有す るのを見るととが出来た。

インドールがトリプトフェンと略同程度の発育効 果を有すること及びインドール誘導体つ発育効果は， インドールに遥加及及゙ないととから、トリプトフ エンの発育作用はインドールの発育作用に直結され ており、トリプトフェンがインドールから合成され るものであるととを推測させる.

Fildes2)（1933）等は元来トリプトフィンを必要 とするが training によつて $\mathrm{NH}_{3}$ 塩を唯一のN源 として発育し得る菌株をトリプトフォンを含んでい ない $\mathrm{NH}_{3}$ 塩培地に培養して，その菌体内にトリプ トファンが合成されていることを証明した。

Burrow87)（1939）は $\mathrm{NH}_{3}$ 塩を $\mathrm{N}$ 源として発育 し得るチフス菌株が，少是のトリプトフォンを浱加 した $\mathrm{NH}_{3}$ 塩培地て於て菌体橧淔溪, 検出された卜 リプトフェン量が最初つ添加量より增加しているて とからこの菌侏はトリプトフォンを合成する能力あ りとした。

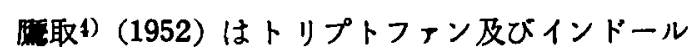
不要で直銷アミノ酸を必要とする菌怢をグルタミン 酸、アスパラギン，及びシスチンを含む培地に培甆 して又, $\mathrm{NH}_{3}$ 塩にて発育し得るように trainingさ れた菌株を $\mathrm{NH}_{3}$ 塩培地化培篦して夫ょの菌体内沉 トリプトフォンが合成されているととを微生物学則 定法によつて証明した。

新井14）(1951）は発育汇トリプトフェンは不要で あるがインドールは必要とする菌株をインドールを 含む培地倍鐜して，又，アスパラギン及びシスチ ンをN源として発育し得る Watson 株をアスパラ ギン及びシスチンを含む培地に培羔して夫なの间体 がトリプトフォンを合戎しているととを Ehrlich
のアルデヒド試薬を用いて吸収スペクトルにより証 明した。

扱，チフス菌に於てトリプトフォンはインドール から合成せられる事は分つたが，では次にインドー ルは何から合成せられるであろうか. . 又, トリプト フォンは如何にしてインドールから合成せられるで あろうかが問題となる.

ての点江関して, Neurospora の生化学的ミュー タント15)ではトリプトファンの生合成は次式の如 くアントラニール酸からインドールが合成され，次 いでインドールとゼリンとが縮合されてトリプトフ エンが合成せられることが分つている.

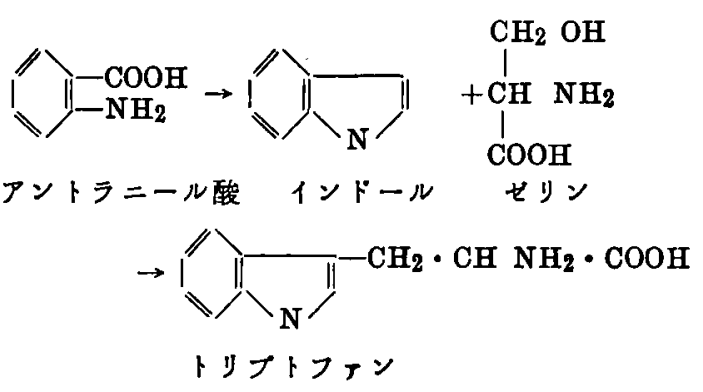

扱, チフス菌纪於て，トリプトファンの生合成が Neurospora の場合の如く行われるかどうかに就い ては次の機会に䇎りたい。

\section{第6 章 結 論}

筆者は教室保存の腸チフス菌10株を用いて次の如 き結果を得た。

1） 10 株の内， 7 株は発育にトリプトフェンを必 要とし残りの 3 株は必要としない.

2）トリプトフォン必要株 $S 58$ はどのアミノ酸を あ単独䎲 $\mathrm{N}$ 源として利用し得ないが, トリプトフォ ン不要棶 $\$ 60$ はグルタミン酸, シスチン, アスパラ ギン酸を単独:てN源として利用する。特にグルタミ ン酸をよく利用する.

3） S58 はトリプトフォンを欠くと全く発育はみ られず, シスチンを欠くと発育が非常に劣り，次い でアスパラギン酸を欠くと発育が大分劣る。こ机に 反して $\mathbf{S 6 0}$ はトリプトフォンを欠いても発有は少し あ影響さ机ず，むしろシスチンを欠くと発育が非常 に少り，次いでアスパラギン酸を欠くと発育が大分 劣る.

4）トリプトフェンは 10-8M 䟴度でも発育効果 を有する．とのとと及び上述つトリプトフォンを欠 くと全く発育刀みられないことから，トリプトフォ ンはトリプトフェン必要件にとつて“烧青囚子”に 
あたると思われる。

䅂りと臨み終始御愁篤なる御指導と御校閲を睗つ

5）インドールはトリプトフォンと略同程度の発 た恩師村上教授に深甚の謝意を表し，併世て御協力 育効果を有する.

下さつた中桐，瀨尾両嬂に感謝する次第であります。

6） イント゚ール醋酸，スカトールは幾分発育効果

を有するが、インドールに比べるとずつと弱い。

1) Koser, Rettger : J. Infect. Dis., 24, 301, 1919.

2) Fildes. Gladstone, Knight : Brit. J. Exptl. Path., 14, 189, 1933.

3) Johnson, Rettgér : J. Bact,, 43, 103, 1942. ; 45, 127, 1943.

4) 取：日本細菌学椎誌. 7巻, 3号, 245, 1952.

5) Van. Loghem : Zent. Bact. Parasitenk. I. Orig., 57, 385, 1911.

6) Braun, Cahn-Bronner : Zent. Bact. Parasitenk. I. Orig., 86, 196, 1921. ; Biochem Z., 131, 226, 272, 1922.

7) Burrows : J. Infect. Dis., 64, 145, 1939.

8) Saunders, Finkle : J. Am. Chem, Soc. 59, 170, 1937.

9) 新井: 楽学雑誌, 70巻, 6号, 311, 1950.

10) Fischer, A. : Vorlesungen über Bakterien. 2.

\section{文献}

Aufl. Jena. 97, 1903.

11) P. Fildes : Brit. J. Exptl. path., 21, 315, 1940.

12) Wooley, Sebrell . J. Biol. Chem., 157, 141, 1945.

13）大谷，本田：大阪医学会雑誌，37，1, 昭和13年.

14) 新井：薬学雑誌, 71 巻, 691, 1951.

15) Yanofsky, C. : A symposium on Amino Acid Metabolism, Johns Hopkins Press, 930, 1955.

16）水野，小坂·日本細菌学雑誌，5，53，59，1950. $7,227,229,1952$.

17) Gale, E. F.：細菌の化学的活性, 本田書店, 91, 1953.

18) Oginsky, Umbreit：細菌生理学入門，丸善株式 会社, 63, 1953.

19）Lamanna, Mallette：基碟細菌学, 丸善株式会 社, 336, 1953. 


\title{
Studies on the Tryptophan Metabolism of Bacteria
}

\section{Tryptophan metabolism of B. typhosus.}

\author{
$\mathrm{By}$ \\ Minoru Inada \\ Department of Microbiology, Okayama University Medical School \\ (Director : Professr Dr, SakaeMurakami)
}

It is well known that tryptophan is necessary for the growth of B. typhosus.

The anthor analyzed this requirement of tryptophan from the point of view of the nutritive requirement of $B$. typhosus. The results were as follows:

1) Of ten strains, seven strains require tryptophan for growth, three strains do not.

2) S-58 which requires tryptophan utilizes no amino acid singlely as $\mathrm{N}$ source and S-60 which does not require tryptophan utilizes singlely glutamic acid, cystine and aspartic acid. Glutamic acid is especially utilized by $\mathrm{S}-60$.

3) S-58 does not grow in the absence of tryptophan and grows scarcely in the absence of cystine and grows a little in the absence of aspartic acid. On the contrary s-60 grows in the presence or absence of tryptophan and grows scarcely in the absence of cystine and grows a little in fhe absence of aspartic acid.

4) Tryptophan has the effect on growth at 10-8 Mol. From this and the fact that above mensioned the strain which requires tryptophan could not grow in the absence of tryptophan tryptophan is fouud to be "growth factor" fot the strain.

5) Indole is found to be approximately equally effective as tryptophan.

6) Indole acetic acid and skatole is more weak effective compared with indole. 